\title{
MONIKA GOŁĄB-KORZENIOWSKA
}

Instytut Projektowania Miast i Regionów

Wydział Architektury

Politechnika Krakowska im. Tadeusza Kościuszki

\section{ROZWÓJ PRZESTRZENNY MALEGO MIASTA - FORMA MIEJSKA CZY PODMIEJSKA PRZYKLAD SLOMNIK \\ SPATIAL DEVELOPMENT OF A SMALL TOWN - URBAN OR SUBURBAN FORM THE EXAMPLE OF SLOMNIKI}

Artykuł wpłynął do redakcji 08.02.2016; po recenzjach zaakceptowany 15.09.2016.

Gołąb-Korzeniowska M., 2016, Rozwój przestrzenny małego miasta-forma miejska czy podmiejska, [w:] Bartosiewicz B. (red.), Tendencje w rozwoju gospodarczym i przestrzennym matych miast $w$ Polsce. Trends in economical and spatial development of small towns in Poland, „Space - Society - Economy", 17, Institute of the Built Environment and Spatial Policy, Wydawnictwo Uniwersytetu Łódzkiego, Łódź, s. 29-47.

Dr inż. arch. Monika Gołą-Korzeniowska, Instytut Projektowania Miast i Regionów, Wydział Architektury, Politechnika Krakowska im. Tadeusza Kościuszki,ul. Warszawska 24,31-155 Kraków; e-mail:monikaczajowice@gmail.com

\section{Zarys treści}

Artykuł koncentruje się na zagadnieniach formy małego miasta, której ewolucja jest determinowana wprowadzaniem ustaleń miejscowego planu. Badania aktualnego zagospodarowania terenu i jego uwarunkowań przestrzennych pozwalają na diagnozowanie najistotniejszych problemów struktury miasta. Analiza miejscowego planu zagospodarowania przestrzennego umożliwia określenie charakteru przestrzeni, która może pojawić się w trakcie jego realizacji, skutków dla porządkowania zabudowy i czytelności układu. Badania przeprowadzono dla miejscowości Słomniki, która jest przykładem małego miasta o zachowanym średniowiecznym rozplanowaniu i typowymi dla małych miast przekształceniami tkanki miejskiej. Równocześnie miasto jest w całości objęte miejscowym planem zagospodarowania przestrzennego uchwalonym w 2015 roku. Celem podjętych badań jest określenie, czy forma przestrzenna 
jaką przyjmą Słomniki w wyniku realizacji ww. planu będzie kontynuacją ich miejskiego charakteru czy zostanie zdominowana jednorodzinnymi osiedlami upodabniając się do podmiejskiego osiedla. Badania stanowiły rozpoznanie aktualnego stanu zagospodarowania, diagnozujące obecne tendencje w rozmieszczaniu zabudowy oraz zapisy planu sprawdzane pod kątem przyszłego kształtu przestrzeni miasta. Konkluzją artykułu jest stwierdzenie, że realizacja planu daje możliwość utrzymania małomiejskiego charakteru przestrzeni, jednak elastyczność zapisów nie jest tego gwarantem. Dlatego niezwykle istotnym elementem lokalnej polityki przestrzennej jest konsekwencja w przedstawionej w planie polityki przestrzennej.

\section{Slowa kluczowe}

Małe miasto, forma miejska, miejscowy plan zagospodarowania przestrzennego, Słomniki.

\subsection{WPROWADZENIE}

Pośród form przestrzennych zabudowy, forma miejska, najbardziej złożona i najbardziej odpowiadająca społecznym potrzebom człowieka, w sposób szczególny przekłada się na małe miasto ze względu na jego skalę i wynikającą z niej kameralność, ograniczoność przestrzenną, powiązanie z otaczającym krajobrazem, dominację historycznego układu (Gzell 1996).

Problematyka formy małego miasta pojawia się w szeregu opracowaniach z zakresu urbanistyki w odniesieniu do kompozycji urbanistycznej czy konsekwencji przebudowy przestrzeni wynikającej z sytuacji społeczno-gospodarczej i demograficznej oraz towarzyszących im zmianom funkcjonalnym. Wśród pozycji bibliograficznych poświęconych temu zagadnieniu wyjątkowe znaczenie posiadają opracowania H. i K. Wejchertów. Prowadzone przez nich, prawie czterdziestoletnie prace, rozpoczęte po odzyskaniu przez Polskę niepodległości w 1945 roku zostały zebrane w książce pt. Małe miasta. Problemy urbanistyczne stale aktualne wydanej w 1986 roku (Adamczewska-Wejchert, Wejchert 1986). Wskazują rolę walorów kulturowych jako ważnego aspektu tworzenia przyszłego obrazu miasta, akcentują wagę tworzenia planów przebudowy. Badania nad miasteczkami prowadzone przez S. Gzella koncentrują się na ich specyficznych cechach i zjawiskach kreujących określony wzorzec planistyczny (Gzell 1996). Wieloaspektowe analizy stanu przestrzeni miasteczek ujmowane dla ich zbiorów (Sokołowski 2000; Gołąb-Korzeniowska 2008; Heffner, Marszał 2011; Wójtowicz-Wróbel 2013) wskazują na prawidłowości i pozwalają na systematyzację wyników badań. Studia poszczególnych przypadków w różnych warunkach przestrzennych dają możliwość ocen porównawczych (Bartosiewicz, Marszał 2011). Wielki wpływ na wizerunek miast mają działania rewitalizacyjne, skupiające się przede 
wszystkim w obszarach staromiejskich. Wśród rozważań nad kształtowaniem przestrzeni publicznej na uwagę zasługuje publikacja pt. Przestrzeń publiczna małych miast (Czepczyński 2012; Groeger 2012) ściśle związana z małymi miastami.

Kształt miasta - fizjonomia jest odbiciem mieszkającej tradycji, aspiracji, zasobności i zróżnicowania społecznego mieszkańców, ale także polityki władz lokalnych. Indywidualność jego formy decyduje o atrakcyjności, pozwala na identyfikowanie się z nim mieszkańców. Główne cechy przestrzeni miejskiej to przede wszystkim zwartość zabudowy i hierarchiczność struktury funkcjonalno-przestrzennej wskazujące na ważniejsze i mniej istotne fragmenty - przeznaczone dla wszystkich użytkowników, i bardziej kameralne - wykorzystywane przez ograniczoną ilość osób. Czytelność układu zapewniają przede wszystkim linie zabudowy wzdłuż ulic i placów, dominanty, charakterystyczne obiekty. Ogólnodostępne miejsca tworzą sieci przestrzeni publicznych, a różnorodność funkcji miejskich odzwierciedla się w bogactwie form domów.

Sąsiadujące z miastem zainwestowane tereny podmiejskie wywołują pewnego rodzaju ,anarchię" przestrzenną pozbawioną przestrzeni publicznej, przeważnie monofunkcyjną o amorficznym układzie. Najczęściej tworzą je rozproszone zespoły domków jednorodzinnych, a wmieszane w nie obiekty usług lub produkcyjne deformują drobną strukturę zabudowy.

Wsie, osady o rozluźnionym rozmieszczeniu budynków uszeregowanych wzdłuż drogi posiadają swoją wyodrębnioną strefę centralną, zazwyczaj koncentrującą się przy kościele lub innych ważnych usługach. Powstające tu aktualnie domy coraz częściej tracą związek z produkcją rolną upodabniając tereny wsi do podmiejskich osiedli. W miarę rozrastania się miasta, wchłaniane do jego wnętrza wsie lub ich przysiółki, tworzą kolejne ogniska koncentracji budynków.

Kierunek jaki przybierze kształt rozrastającego się miasta wyznaczają regulacje w dokumentach planistycznych.

Artykuł ma na celu wykazać, w jakim zakresie wprowadzanie ustaleń miejscowego planu zagospodarowania przestrzennego dla małego miasta pozwala na utrzymanie lub przywrócenie jego miejskiego charakteru, w odniesieniu do aktualnego stanu zagospodarowania. Powyższa problematyka została omówiona na przykładzie Słomnik.

Badania wykonane dla Słomnik koncentrowały się na analizie zapisów aktualnego miejscowego planu zagospodarowania przestrzennego, zwracając szczególnie uwagę na parametry kształtowania zabudowy oraz przyjęte wielkości nowo wydzielanych działek. Pozwoliło to na określenie kierunku, w jakim będzie następować przebudowa i rozwój miasta. Wyniki tej analizy zestawiono z wielkościami działek oraz ich sposobem zagospodarowania. Wykonane zostały również badania terenowe pozwalające na wyodrębnienie odmiennych przestrzennie 
układów zabudowy i sklasyfikowanie ich pod kątem cech miejskiej struktury: zwartości, gabarytów, linii zabudowy, ustawieniem w stosunku do ulic. Podbudową badań były historyczne plany miasta i informacje zawarte $\mathrm{w}$ materiałach źródłowych (Wójtowicz-Wróbel 2008; Malik 2013).

\subsection{SŁOMNIKI - STAN PRZESTRZENI MIASTA}

Słomniki to przykład małego miasta, którego forma zapoczątkowana XIV-wiecznym układem lokacyjnym rozrasta się w sposób typowy dla niewielkich ośrodków o stosunkowo słabych podstawach rozwojowych. Miasto znajduje się w rejonie rolniczym. Pomimo położenia w odległości około $25 \mathrm{~km}$ od Krakowa i dobrej dostępności komunikacyjnej, nie podlega silnej urbanizacji związanej z sąsiedztwem dużego miasta. Aktualnie zamieszkiwane jest przez 4434 osoby (GUS 2014). Liczba mieszkańców posiada stosunkowo stabilną wielkość (ubytek mieszkańców miasta w ciągu ostatnich 12 lat oceniany jest na około $0,2 \%$ ). Powierzchnia miasta wynosi $3,34 \mathrm{~km}^{2}$, w tym zainwestowanie miejskie obejmuje około $1,18 \mathrm{~km}^{2}$. Posiada czytelny układ miejski o zwartej zabudowie. Najbliższe otoczenie miasta stanowią pola uprawne.

Ze względu na różnorodność struktury zabudowy można wymienić rejony miasta o odmiennej jej strukturze. Rozmieszczenie omawianych zespołów przedstawia rys. 1.

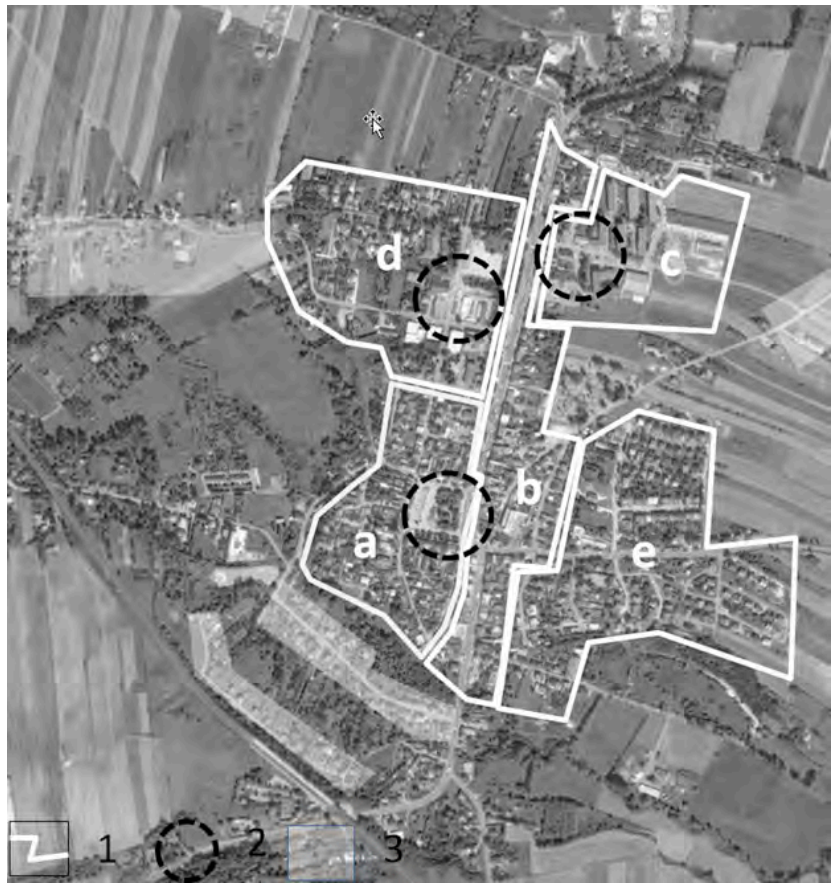

1 - granice wydzielonych rejonów miasta

2 - miejsca koncentracji usług posiadające charakter przestrzeni publicznych

3 -główne kierunki rozwoju pasm zabudowy

a - obszar staromiejski

$\mathrm{b}$ - główna ulica miejska $\mathrm{z}$ otoczeniem

c-zespół zabudowy wielorodzinnej i koncentracji usług publicznych

d - zespół wielofunkcyjny z wielkopowierzchniowymi budynkami

e - zespoły zabudowy jednorodzinnej

Rys. 1. Rejony miasta o odmiennej strukturze zabudowy Źródło: opracowanie własne 


\section{a) Obszar staromiejski}

Słomniki zostały lokowane w XIV wieku w oparciu o prawo średzkie (Malik 2013). Ich centralne miejsce zajmuje kwadratowy rynek o boku ok. 130 m, wokół którego wytyczono bloki miejskie. Miasto wzniesiono na wzgórzu opadającym w kierunku południowym w stronę doliny rzeki Szreniawy. W miarę rozwoju, prowadzona po wzgórzu zabudowa utworzyła malowniczą sylwetę zwieńczoną wieżami kościoła. Topografia terenu urozmaica widoki pozwalając na dostrzeżenie z wąskich uliczek otaczający rolniczy krajobraz. Niewiele zachowało się historycznych budynków. Najstarsze obiekty pochodzą z XIX wieku (Uchwata... 2015, s. 11-13) Zabudowa starówki jest bardzo zniszczona. Odbudowywane i przebudowywane domy o różnych gabarytach, w dużej części posiadają zły stan utrzymania, niektóre znajdują się w stanie ruiny (fot. 1). Widoczne są ubytki w zabudowie i niezagospodarowane działki. Nie najlepszy jest również stan zabudowy przyrynkowej. Podobnie cechy dewastacji dotyczą ulic, chodników i towarzyszącej im zieleni. Wybrukowana płyta rynku wykorzystywana jest głównie do parkowania samochodów (fot. 2).

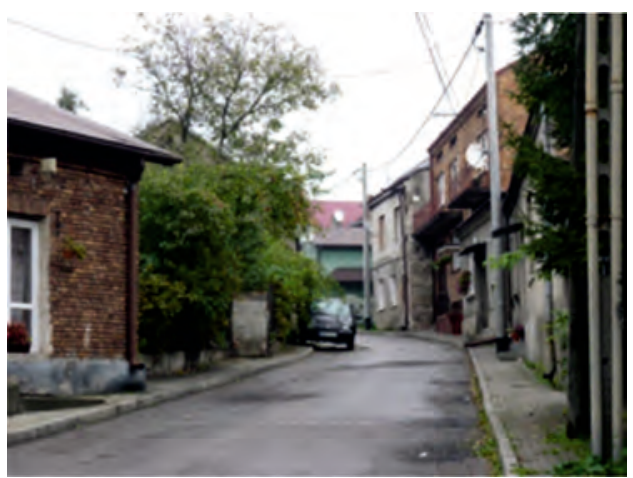

Fot. 1. Zniszczona zabudowa centralnej części Słomnik, ul. Grunwaldzka fot. Monika Gołą-Korzeniowska

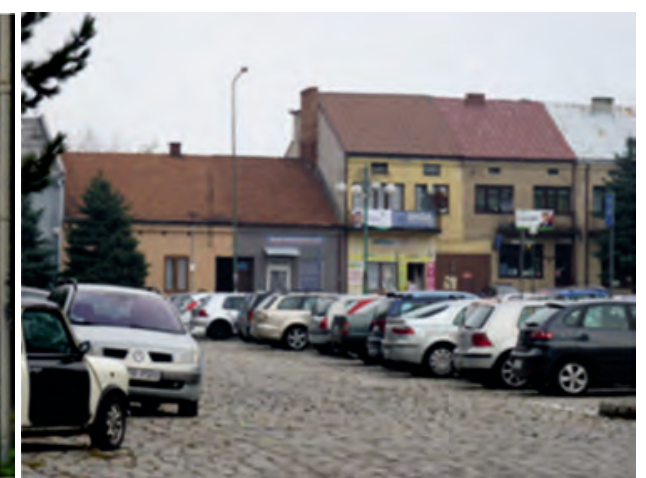

Fot. 2. Płyta Rynku - główny parking w mieście fot. Monika Gołą-Korzeniowska

\section{b) Główna ulica miejska z otoczeniem}

Główna ulica miasta - ul. Kościuszki, tworząca podstawowy element szkieletu miasta, wyprowadza ruch $\mathrm{z}$ rynku na północ w kierunku osiedla wielorodzinnego. Jest ona równocześnie drogą kategorii krajowej (DK7) o bardzo dużym natężeniu ruchu tranzytowego. Dwudziestometrowy korytarz pomiędzy budynkami o szerokich chodnikach $(7-11 \mathrm{~m})$ po obu stronach jezdni ogranicza zwarta ściana budynków mieszkalno-usługowych, w przewadze jednopiętrowych z lokalami usługowymi w parterach. Kwartały uliczne po jego wschodniej i zachodniej 
stronie zabudowane są domami mieszkalnymi z różnych okresów XX wieku, głównie po II wojnie światowej. W kwartałach zewnętrznych zabudowa ma rozluźniony układ. Zauważyć tu można zniszczone obiekty i zaniedbane nawierzchnie, niewyrównane gabaryty domów, skromny detal, jak również starannie utrzymane budynki i ich otoczenie. Całość w odbiorze oddaje specyfikę małego miasta.

\section{c) Zespół zabudowy wielorodzinnej i koncentracji usług publicznych}

W Słomnikach wielorodzinne bloki mieszkalne znajdują się w dwóch miejscach. Dwa bloki przy ul. Kolejowej są niskimi, dwupiętrowymi budynkami, niewyróżniającymi się wysokościowo. Drugi zespół to osiedle sześciu bloków pięciokondygnacyjnych powstałych w latach 70 . ubiegłego stulecia, poszerzone o oddany do użytkowania w 2015 roku nowy czterokondygnacyjny budynek mieszkalny (fot. 3,4). Jego usytuowanie, poprzecznie do istniejących, stanowi początek przewidywanej rozbudowy osiedla, uzależnionej zapewne od zainteresowania kupnem mieszkań. Zespołowi towarzyszy rozległy, trzypiętrowy budynek szkoły, hala sportowa, przedszkole, planowana jest tu także budowa ośrodka zdrowia. W najbliższym otoczeniu funkcjonuje Urząd Miasta i Gminy i inne obiekty usługowe. Znaczenie funkcjonalne obszaru wskazuje na jego wagę dla miasta jako centrum. Całość, pomimo struktury zabudowy zdecydowanie odmiennej od tradycyjnego miasta tworzy spójną całość, aktualnie uzupełnianą nowoczesną architekturą.

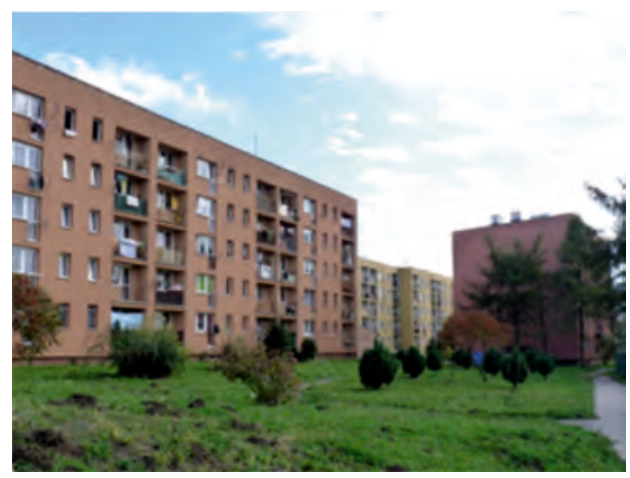

Fot. 3. Budynki blokowe z lat 70. ubiegłego wieku - osiedle Świerczewskiego.

Najwyższe budynki mieszkalne w Słomnikach pozbawione cech zabudowy małomiasteczkowej fot. Monika Gołą-Korzeniowska

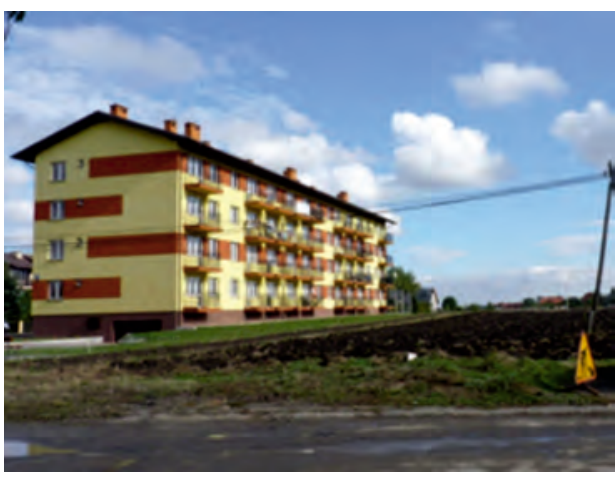

Fot. 4. Nowo powstały budynek wielorodzinny stanowiący rozbudowę osiedla Świerczewskiego fot. Monika Gołą-Korzeniowska 


\section{d) Zespół wielofunkcyjny o znacznej koncentracji zabudowy}

Zagospodarowanie terenu znajdującego się poniżej wzgórza, po zachodniej stronie miasta, sprawia wrażenie odrębnego zespołu, nie spójnego wewnętrznie, gromadzącego budynki wielkopowierzchniowe (fot. 5). Z racji położenia w obniżeniu terenu, obiekty halowe (produkcyjne i handlowe) nie wybijają się wysokościowo ponad zabudowę miasta, jedynym akcentem jest komin przy hali produkcyjnej, dominują natomiast powierzchniowo. Zespół dopełniają w tym rejonie: budynek centrum kultury z remizą OSP i bank, a od zachodniej strony wzniesione, na zróżnicowanych wielkościowo działkach, domy jednorodzinne, często duże, o rozczłonkowanej bryle. Obszar ten zaczął zabudowywać się z końcem lat 80., choć większość budynków powstała w ostatnich latach. Nie stanowią atrakcyjnej wizualnie grupy, podobnie jak znajdujący się obok plac targowy.

\section{e) Zespoły zabudowy jednorodzinnej}

W Słomnikach przeważa zabudowa jednorodzinna. Można wyodrębnić w obszarze miasta jej różne układy. Poza omawianymi terenami, gdzie w zwartych, typowo małomiasteczkowych strukturach uzupełniana jest kamieniczkami lub budynkami usługowymi, koncentruje się w enklawach o zbliżonych cechach zabudowy.

Należą do nich:

- osiedle składające się z sześciennych domów przykrytych kopertowymi dachami o niewielkim spadku, ustawionymi na jednakowych działkach. Występują tu domy wolnostojące, bliźniacze i szeregowe. Zgeometryzowany układ ulic z wydzielonymi obustronnie chodnikami i zachowaną linią zabudowy posiada charakter miejskiej ulicy ${ }^{1}$.

- największe powierzchniowo zgrupowanie indywidualnych domów o podobnych parametrach działek i wielkości budynków, powstałe i rozwijane w oparciu o jedną z ważniejszych dróg wychodzących z miasta. Zespół ten tworzy sieć uliczek o drobnej strukturze domków jednorodzinnych miejscami łączącymi się w szereg. Mniej czytelne układy zabudowy związane z miękkim przebiegiem ulic i nieregularnym podziałem na działki, różnorodność ogrodzeń i brak chodników decydują o wyrazie przestrzennym typowym dla mieszkalnej strefy podmiejskiej (fot. 6).

- ciągi zabudowy wzdłuż ulic o różnych okresach powstania i architekturze. Liniowe układy domów rozciągają się w dolinie Szreniawy i Młynówki, wzdłuż dróg wychodzących z miasta na zachód w stronę stacji kolejowej,

${ }^{1}$ Osiedle „Poetów” jest położone we wschodniej części miasta. Jest pierwszym jednorodzinnym osiedlem w Słomnikach powstałym po II wojnie światowej w efekcie jednakowej parcelacji terenu. Budynki zaczęły powstawać w latach 70. ubiegłego wieku. 
równoległej do niej drogi szczytem wzgórza i w kierunku wschodnim. Tu pojedyncze budynki, związane w przeszłości z gospodarstwami rolnymi uzupełniane są jednorodzinnymi, przekształcając się w podmiejskie pasma zabudowy.

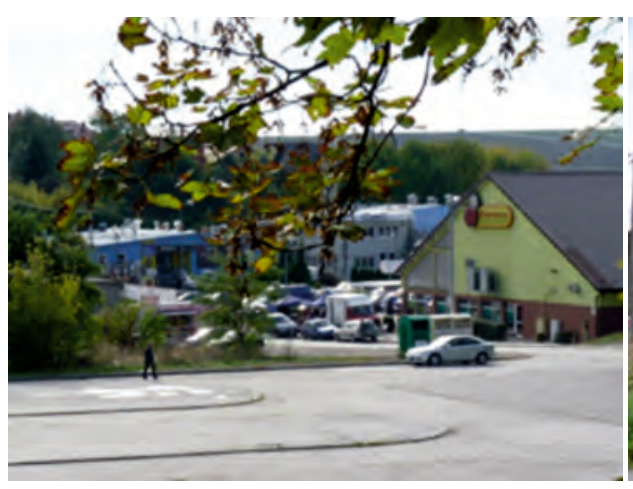

Fot. 5. Koncentracja zabudowy halowej - widok z płyty placu targowego fot. Monika Gołab-Korzeniowska

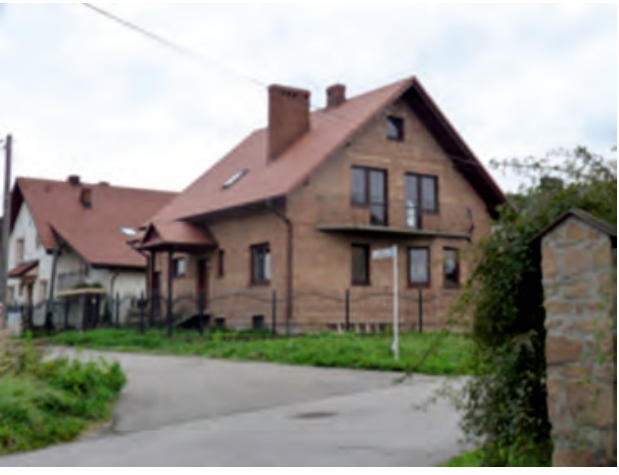

Fot. 6. Współcześnie wznoszone domy jednorodzinne - ul. Kossaka fot. Monika Golab-Korzeniowska

\subsection{PRZESTRZEŃ PUBLICZNA}

Sieć przestrzeni publicznych w Słomnikach tworzy Rynek oraz ul. Kościuszki (DK7) i odchodząca od niej ul. Świerczewskiego. Życie miejskie koncentruje się również przy wielkopowierzchniowych obiektach handlowych (Biedronka i Mrówka), a w dni targowe na płycie placu targowego i w jego otoczeniu. Główna przestrzeń publiczna, jaką jest płyta rynku służy przede wszystkim na cele komunikacyjne - poza parkingiem, znajduje się tam końcowy przystanek busów. W najbliższym czasie powierzchnia rynku zostanie przebudowana w celu podniesienia jej walorów estetycznych oraz przystosowania do potrzeb miejsca spotkań mieszkańców. Poza rynkiem nie występują obiekty małej architektury stanowiące wyposażenie przestrzeni publicznej. Wewnątrz miasta nie ma czytelnych powiązań pomiędzy obszarami koncentracji aktywności społecznej.

\subsection{STRUKTURA ZABUDOWY}

Opisane powyżej zespoły wydzielone zostały ze względu na swoją odrębność wizualną i rodzaj funkcjonowania. Jako najbardziej odpowiedzialne za czytelność struktury miasta należy przyjąć proporcje pomiędzy powierzchnią działek i jej zabudową oraz parametry wnętrz ulic i placów. Wielkość działek przeznaczona pod zabudowę jest uzależniona od położenia w obszarze miasta. Najdrobniejszy podział występuje na terenie centrum miasta, w obszarze zainwestowanym do 
okresu I wojny światowej (rys. 2), a zwłaszcza w najstarszej jego części. Powierzchnia działek wynosi tutaj około 2-3 ary, w szczególności na śródmiejskim wzgórzu. Stojącym na nich domom o powierzchni zabudowy 100-110 m² zazwyczaj towarzyszą dodatkowo budynki gospodarcze, przez co ponad połowa działki jest zabudowana. W blokach przyrynkowych działki są większe. W pierwotnym podziale lokacyjnego miasta szerokość frontów budynków wynosiła ok. 6,75-7 m (Malik 2013, s. 49). Obecnie działki przyrynkowe mają szerokości frontów od 7,5 do $17 \mathrm{~m}$, najczęściej w granicach około 12-14 m. Wysokość zabudowy okalającej 1,7 hektarowy rynek wynosi 1-2 kondygnacji (choć znajduje się również budynek 4-kondygnacyjny). Podobne parametry posiadają budynki w zwartej przyulicznej zabudowie.

Dla domów jednorodzinnych budowanych w różnych okresach (od lat powojennych do dziś) przeważają działki 4,5-5,0 arowe o centralnie ustawionym domu, który zajmuje około $25-30 \%$ jej powierzchni. Zewnętrzny obrys budynku waha się pomiędzy $120-160 \mathrm{~m}^{2}$. Podczas gdy w starszej zabudowie dominuje zabudowa piętrowa $\mathrm{z}$ dachem o niewielkim nachyleniu i prostej bryle, to powstałe w ostatnich latach budynki są często parterowe z użytkowym poddaszem, o złożonym rzucie i wielospadowym dachu.

Budynki wielorodzinne blokowe o szerokości $13 \mathrm{~m}$ i długości do $60 \mathrm{~m}$, zajmujące powierzchnię 7,7 ara, są wysokie na $16 \mathrm{~m}$ i rozstawione w odległości 28 metrów od siebie. Największe powierzchniowo budynki w zwartej tkance miejskiej, poza halami produkcyjnymi (szwalnie firmy Rader [11,4 ara] i Gramp Croll [6,2 ara]), to wielkopowierzchniowe sklepy o powierzchni 9,8 ara (Biedronka) i 8 ara (Mrówka).

Ciągi uliczne $\mathrm{w}$ najgęściej zabudowanych obszarach miasta wynoszą od $7,5 \mathrm{~m}$ dla bocznych uliczek do $20 \mathrm{~m}$ (główna ulica), tworząc wnętrza o proporcjach ścian do płaszczyzny drogi od 1,3 do 0,5 . W zewnętrznych jednorodzinnych terenach wielkość proporcji to około 0,4 , ze względu na odsunięcie ścian budynków w głąb działek. W obszarze miasta zaniknęła zabudowa typowo wiejska, pomimo rolniczych funkcji najbliższego sąsiedztwa.

Słomniki posiadają drobną strukturę zabudowy, złożoną z niewielkich gabarytowo domków postawionych na małych działkach, w obszarach centralnych silnie skoncentrowaną. W najstarszym fragmencie miasta występują ubytki w zabudowie. Wysokość budynków w przewadze to jedna lub dwie kondygnacje. Budynki halowe, pomimo dużych powierzchni, nie wybijają się wysokościowo, co wynika z położenia jednopoziomowych hal w obniżeniu terenu. Bloki wielorodzinne, wyróżniające się wysokością, nie wchodzą w relacje widokowe z dominantą wież kościelnych i sylwetą miasta.

${ }^{2}$ Fragment mapy przedstawiający zasięg zabudowy Słomnik w 1914 roku z Archiwum Map WIG, KdwR_F41_Slomniki_1914_600dpi.jpg, http://igrek.amzp.pl/details. php?id $=10841$. 
Na czytelność formy miasta wpływa zwartość zabudowy, obszerny rynek krystalizujący układ miejski i charakterystyczna bryła kościoła widoczna ze wszystkich stron miasta.

Działania, jakie powinny być podjęte w celu utrzymania małomiasteczkowego charakteru Słomnik, równocześnie poprawiając jakość przestrzeni i zapewniając harmonijny rozwój, to:

- przywrócenie rynkowi funkcji głównej przestrzeni publicznej miasta,

- stworzenie warunków do uporządkowania przyrynkowych kwartałów oraz pozostałych terenów historycznego miasta,

- remonty, uzupełnienia, uporządkowanie, modernizacja, wymiana substancji, wzbogacenie funkcjonalne, wyrównanie gabarytów w obszarach o zdegradowanej substancji miejskiej,

- odwzorowanie w przestrzeni hierarchii funkcjonalnej terenów zabudowy, uczytelnienie powiązań przestrzeni publicznych i ich zagospodarowanie,

- zapewnienie zwartości zabudowy i kontynuacji jej istniejących parametrów, utrzymanie linii zabudowy.

Przestrzeń Słomnik posiada szereg cech, które wskazują na jej kryzysowy stan. Objawia się to przede wszystkim złym stanem utrzymania budynków i terenu, brakiem spójności formy architektonicznej, nieatrakcyjną przestrzenią publiczna, skłonnością do rozpraszania zabudowy na obrzeżach miasta, przypadkowością lokalizacyjną znaczących obiektów. Przeciwdziałać tej sytuacji może polityka przestrzenna gminy wyrażona m.in. w uchwaleniu miejscowego planu zagospodarowania przestrzennego dla całego terenu miasta.

\subsection{REGULACJE FORMY PRZESTRZENNEJ MIASTA W MIEJSCOWYM PLANIE ZAGOSPODAROWANIA PRZESTRZENNEGO}

Słomniki są miastem, dla którego został uchwalony miejscowy plan zagospodarowania przestrzennego (mpzp) w jego administracyjnych granicach (Uchwata... 2015). Stwarza to szanse oceny możliwości utrzymania charakteru małego miasta. Najcenniejszym elementem planu jest wyraźne rozgraniczenie obszarów podlegających urbanizacji od otwartych, wyłączonych spod zabudowy. Ta granica decyduje o zwartości miasta i jakości krajobrazu. Wskazane w planie wskaźniki i parametry pozwalają na określenie ograniczeń i możliwości zmian przestrzennych wprowadzanych dla wydzielonych terenów. Efekty podejmowanych działań powinny prowadzić do spójności przestrzennej. Należy jednak brać pod uwagę, że na ukształtowanie budynków i ich otoczenia wpłyną współczesne wzorce estetyczne, potrzeby i możliwości mieszkańców. Znacząca większość inwestycji mieszkaniowych i komercyjnych będzie realizowana przez inwestorów prywatnych. 


\subsubsection{WIELKOŚCI DZIALEK ORAZ KSZTALTOWANIE ZABUDOWY - PARAMETRY I WSKAŹNIKI}

Podstawowym sposobem ochrony, przekształcania i tworzenia struktury zabudowy jest określenie jej rozmieszczenia, wielkości działek oraz gabarytów budynków. Tab. 1 przedstawia zestawienie najważniejszych parametrów dla terenów przeznaczonych pod zabudowę wskazaną w miejscowym planie zagospodarowania przestrzennego.

Tabela 1

Podstawowe parametry i wskaźniki dla terenów przeznaczonych pod zabudowę określone w miejscowym planie zagospodarowania przestrzennego Słomnik

\begin{tabular}{|c|c|c|c|c|}
\hline $\begin{array}{l}\text { Przeznaczenie } \\
\text { terenów }\end{array}$ & $\begin{array}{l}\text { Wskaźnik terenu } \\
\text { biologicznie } \\
\text { czynnego/ } \\
\text { powierzchni } \\
\text { zabudowy }\end{array}$ & $\begin{array}{c}\text { Minimalna } \\
\text { powierzchnia } \\
\text { nowo wydzie- } \\
\text { lanych działek/ } \\
\text { Minimalna } \\
\text { szerokość nowo } \\
\text { wydzielanych } \\
\text { działek }\end{array}$ & $\begin{array}{l}\text { Maksymalna } \\
\text { wysokość } \\
\text { zabudowy }\end{array}$ & $\begin{array}{c}\text { Geometria } \\
\text { dachu }\end{array}$ \\
\hline $\begin{array}{l}\text { Tereny zabudowy } \\
\text { mieszkaniowej } \\
\text { wielorodzinnej } \\
(\mathrm{MW})^{3}\end{array}$ & $\min 25 \% / \max 65 \%$ & $800 \mathrm{~m}^{2} / 16 \mathrm{~m}$ & $\begin{array}{c}16 \mathrm{~m} \text { (max 5-kond.) } \\
\text { dla } 5 \mathrm{MW}-12 \mathrm{~m} \text {, } \\
\text { budynki usługowe } \\
\text { i garaże wielopo- } \\
\text { ziomowe-12 m }\end{array}$ & $\begin{array}{c}\text { dwu- i wielospa- } \\
\text { dowy o nachyleniu } \\
12^{\circ}-45^{\circ} \\
\text { lub płaski }\end{array}$ \\
\hline $\begin{array}{l}\text { Tereny zabudowy } \\
\text { mieszkaniowej } \\
\text { jednorodzinnej } \\
(\mathrm{MN})\end{array}$ & $\begin{array}{c}\text { wolnostojące: } \\
\text { min } 30 \% / \max 50 \% \\
\text { bliźniacze: } \max 55 \% \\
\text { szeregowe: } \max 60 \%\end{array}$ & $\begin{array}{l}\text { wolnostojące: } \\
400 \mathrm{~m}^{2} / 16 \mathrm{~m} \\
\text { bliźniacze: } \\
350 \mathrm{~m}^{2} / 12 \mathrm{~m} \\
\text { szeregowe: } \\
250 \mathrm{~m}^{2} / 8 \mathrm{~m} \\
\end{array}$ & $\begin{array}{c}12 \mathrm{~m} \text { (max 2-kond.) } \\
\text { dop. } \mathrm{z} \text { usługami } \\
\text { 3-kond. }\end{array}$ & $\begin{array}{c}\text { dwu- i wielospa- } \\
\text { dowy o nachyleniu } \\
30^{\circ}-45^{\circ} \text { (kalenica } \\
\text { równoległa do } \\
\text { dłuższego boku) }\end{array}$ \\
\hline $\begin{array}{l}\text { Tereny zabudowy } \\
\text { mieszkaniowej } \\
\text { śródmiejskiej } \\
\text { (MM) }\end{array}$ & $\min 10 \% / \max 85 \%$ & $250 \mathrm{~m}^{2} / 7 \mathrm{~m}$ & $15 \mathrm{~m}$ (max 3-kond.) & $\begin{array}{l}\text { dwu- i wielospa- } \\
\text { dowy o nachyleniu } \\
\text { głównych połaci } \\
\text { w przedziale } \\
20^{\circ}-45^{\circ}\end{array}$ \\
\hline $\begin{array}{l}\text { Tereny zabudowy } \\
\text { mieszkaniowo- } \\
\text {-usługowej } \\
\text { (MU) }\end{array}$ & $\min 30 \% / \max 60 \%$ & $\begin{array}{l}\text { wolnostojące: } \\
400 \mathrm{~m}^{2} / 16 \mathrm{~m} \\
\text { bliźniacze: } \\
350 \mathrm{~m}^{2} / 12 \mathrm{~m} \\
\text { szeregowe: } \\
250 \mathrm{~m}^{2} / 8 \mathrm{~m}\end{array}$ & $12 \mathrm{~m}$ (max 3-kond.) & $\begin{array}{l}\text { dwu- i wielospa- } \\
\text { dowy o nachyleniu } \\
\text { głównych połaci } \\
\text { w przedziale } \\
20^{\circ}-45^{\circ}\end{array}$ \\
\hline
\end{tabular}

${ }^{3}$ Skróty literowe oznaczają symbole przyjęte w miejscowym planie zagospodarowania przestrzennego dla przyjętego przeznaczenia terenów. 
Tabela 1 (cd.)

\begin{tabular}{|c|c|c|c|c|}
\hline $\begin{array}{l}\text { Przeznaczenie } \\
\text { terenów }\end{array}$ & $\begin{array}{l}\text { Wskaźnik terenu } \\
\text { biologicznie czyn- } \\
\text { nego/powierzchni } \\
\text { zabudowy } \\
\end{array}$ & $\begin{array}{c}\text { Minimalna } \\
\text { powierzchnia nowo } \\
\text { wydzielanych } \\
\text { działek/Minimalna } \\
\text { szerokość nowo } \\
\text { wydzielanych } \\
\text { działek }\end{array}$ & $\begin{array}{c}\text { Maksymalna } \\
\text { wysokość } \\
\text { zabudowy }\end{array}$ & $\begin{array}{c}\text { Geometria } \\
\text { dachu }\end{array}$ \\
\hline $\begin{array}{l}\text { Tereny zabudowy } \\
\text { usługowej } \\
\text { (U) }\end{array}$ & $\begin{array}{c}\min 20 \% / \max 70 \% \\
+ \text { plac targowy }\end{array}$ & $800 \mathrm{~m}^{2} / 12 \mathrm{~m}$ & $12 \mathrm{~m}$ (max 3-kond.) & $\begin{array}{c}\text { dwu- i wielospa- } \\
\text { dowy o nachyleniu } \\
12^{\circ}-45^{\circ} \\
(\text { kalenica }- \text { dłuższy } \\
\text { bok })+ \text { inny }\end{array}$ \\
\hline $\begin{array}{l}\text { Tereny zabudowy } \\
\text { usług publicznych } \\
\text { (UP) }\end{array}$ & $\min 20 \% / \max 70 \%$ & $800 \mathrm{~m}^{2} / 12 \mathrm{~m}$ & $\begin{array}{c}12 \mathrm{~m} \text { (max 3-kond.) } \\
\text { lub } \\
15 \mathrm{~m} \text { (max 4-kond.) } \\
\text { oświata kultura } \\
\text { i sport }\end{array}$ & $\begin{array}{l}\text { dwu- i wielospa- } \\
\text { dowy o nachyleniu } \\
12^{\circ}-45^{\circ} \\
\text { (kalenica }- \text { dłuższy } \\
\text { bok) }+ \text { inny }\end{array}$ \\
\hline $\begin{array}{l}\text { Tereny zabudowy } \\
\text { produkcyjno- } \\
\text {-usługowej } \\
\text { (PU) }\end{array}$ & $\min 15 \% / \max 80 \%$ & $800 \mathrm{~m}^{2} / 18 \mathrm{~m}$ & $15 \mathrm{~m}$ & $\begin{array}{c}\text { płaski, jedno-, } \\
\text { dwu-, wielospado- } \\
\text { wy o nachyleniu } \\
\text { do } 40^{\circ}+\text { inny }\end{array}$ \\
\hline
\end{tabular}

Źródło: opracowanie własne na podstawie miejscowego planu zagospodarowania przestrzennego miasta Słomniki (Uchwała... 2015).

A - Plan przewiduje rozwój budynków wielorodzinnych jako rozbudowę istniejącego zespołu. Przyjęte maksymalne wskaźniki nawiązują do gabarytów już istniejących bloków mieszkalnych. Ze względu na możliwości wydzielania dla inwestorów bardzo wąskich działek (16 m) o minimalnej powierzchni 8 arów można spodziewać się wprowadzania niewielkich obiektów. Brak wytycznych dotyczących rozmieszczania budynków oraz dowolność ich formy nie pozwala aktualnie na sprecyzowanie wyrazu przestrzennego zespołu.

B - Tereny zabudowy jednorodzinnej posiadają bardzo elastyczny zapis dopuszczający we wszystkich obszarach przeznaczonych na tę funkcję wprowadzanie domów zarówno w układzie szeregowym, wolnostojącym, jak i bliźniaczym. Zakres jej koncentracji uzależniony będzie od pomysłów indywidualnych inwestorów.

Minimalne wskaźniki wielkości działek i proponowanej powierzchni zabudowy oraz w stosunku do niej dużej wysokości budynków - do 12 m może sprzyjać zagęszczeniu zabudowy. Zwarte ciągi pierzei ulicznej w tych obszarach możliwe są przy realizacji zabudowy szeregowej (dopuszcza się usługowe partery), jednak ze względu na strukturę działek może okazać się trudne do wprowadzenia. Brak 
wskazania podziału obszarów jednorodzinnych na poszczególne typy zabudowy skutkować będzie dużą dowolnością w ich rozmieszczeniu, nie tworząc zespołów o czytelnych układach.

C - Wydzielone w planie tereny śródmiejskie obejmują rejony historycznego miasta oraz częściowo przylegające do drogi DK7. Regulacje dla ich kształtowania mają na celu porządkowanie i uzupełnianie zabudowy, utrzymując zwarte pierzeje uliczne z uwzględnieniem istniejących podziałów własnościowych. Domy w centralnej części miasta mogą powstawać zarówno jako jedno- i wielorodzinne, z możliwością wznoszenia $\mathrm{w}$ granicach działek. Dopuszczenie wysokości $15 \mathrm{~m}$ dla powstających obiektów stwarza niebezpieczeństwo dużego zróżnicowania gabarytów zwłaszcza, że objęte wpisem do ewidencji zabytków domy są

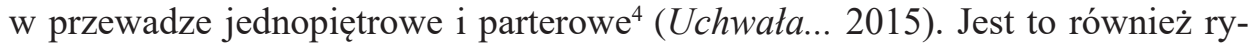
zykowne przy lokowaniu zabudowy na zróżnicowanym wysokościowo terenie. Piętnastometrowe budynki powinny pojawiać się jedynie w określonych warunkach, np. celowo podkreślając przestrzeń przez lokalną dominantę, podkreślenie ważności obiektu lub w sąsiedztwie domu o podobnej wielkości. Utrzymany drobny podział terenu z dopuszczeniem $250 \mathrm{~m}^{2}$ działek oraz $7 \mathrm{~m}$ szerokości wpisuje się w istniejące wielkości.

$\mathrm{D}$ - Zabudowa usługowa jest proponowana $\mathrm{w}$ terenach przylegających do głównej ulicy, która po realizacji obwodnicy miasta ma szansę pełnić rolę głównego ciągu usługowego. Proponowane 12-metrowe budynki mogą wpłyną́ korzystnie na proporcje ulicy, pod warunkiem, że uda się dopasować je do istniejących domów.

E - Tereny usług komercyjnych i tereny usług publicznych mają wyznaczone podobne do siebie parametry w zakresie wielkości kubatur oraz minimalnej powierzchni działek. Ich rozmieszczenie w obszarze miast sugeruje rozwój istniejących już terenów usługowych, a szczególnie zwiększenie ich koncentracji przy osiedlu wielorodzinnym oraz przy budynkach wielkopowierzchniowych. Podniesiony wskaźnik wysokości budynków usług publicznych do $15 \mathrm{~m}$ nawiązuje do gabarytu istniejącej 4-kondygnacyjnej szkoły. Wielkość ta, w odniesieniu do nowo wznoszonych obiektów, zwłaszcza w oddaleniu od osiedla, również wydaje się wykraczającą ponad skalę miasteczka.

F - Zabudowa usługowa i produkcyjno-usługowa, istotna z punktu widzenia rozwoju miasta, jest wskazana w planie w zewnętrznych obszarach peryferyjnych. Rozmieszczone po zewnętrznej stronie obwodnicy urządzenia i obiekty

${ }^{4}$ Aktualnie w Słomnikach, pośród 40 obiektów zabytkowych umieszczonych w gminnej ewidencji zabytków, znajduje się 30 domów pochodzących z przełomu XIX/XX wieku i I poł. XX wieku. Są to budynki parterowe i piętrowe. Jedenaście z nich stoi w Rynku (mpzp 2015). 
produkcyjne wprowadzą zespoły o stosunkowo dużych kubaturach, a ich formę uzależni profil produkcji. Rozmieszczenie tych funkcji w trzech grupach niekorzystnie wpłynie na widzianą z zewnątrz sylwetę miasta.

\subsubsection{KSZTAŁTOWANIE PRZESTRZENI PUBLICZNEJ I UKŁADU MIEJSKIEGO}

Przestrzeń publiczna jest niezwykle ważna dla podkreślenia miejskiego charakteru miejscowości. „Miasto nie istnieje bez wspólnych, publicznych przestrzeni miejskich - to one nadają mu charakter, to tam doświadczamy 'miejskości', to tam spotykamy 'obcego' i negocjujemy relacje społeczne i kulturowe, to tam zachodzą podstawowe interakcje społeczne i par excellance miastotwórcze" (Czepczyński 2012, s. 7). W małym mieście sposób kształtowania tych miejsc z punktu widzenia jego formy i wizerunku ma bardzo istotne znaczenie.

Jako główne przestrzenie publiczne dla Słomnik w miejscowym planie zagospodarowania przestrzennego określone są przede wszystkim ulice w obszarze staromiejskim, ciągi usługowe wzdłuż głównej ulicy miejskiej (ul. Kościuszki - DK7), a także otoczenie usług publicznych oraz wszelkie drogi i ciągi publiczne. Zapis Planu nie konkretyzuje rozwiązań w odniesieniu do nawierzchni, form zagospodarowania, ani ograniczających je ścian. Cenną, jednak bardzo ogólną wytyczną dla tych przestrzeni, jest dążenie do dostosowania ich dla osób niepełnosprawnych. Brakuje doprecyzowania przebiegu głównych połączeń z osiedlami jednorodzinnymi oraz wielkopowierzchniowymi sklepami. Brak ciągłości i przypisanie roli przestrzeni publicznej głównym korytarzom komunikacji kołowej, nie przyniesie oczekiwanych rezultatów, w szczególności jako głównego czynnika integrującego przestrzeń miasta, definiującego jego formę i hierarchizującego strukturę.

W odniesieniu do formy miasta plan reguluje rozmieszczenie zabudowy oraz zasady utrzymania i ochrony podstawowych elementów rozplanowania i kompozycji przestrzennej miasta, tj. układu ulic i placów, linii zabudowy, dominant wysokościowych, osi kompozycyjnych, punktów widokowych, uwzględniającego również relacje z otaczającym krajobrazem. Nie wskazuje jednak wytycznych w tym zakresie dla nowych zespołów. Ustalenia takie decydować mogłyby o wzmocnieniu wizualnym krajobrazu miejskiego, m.in. ze względu na proponowany rozwój, na wzniesieniu zapewniającym ekspozycję widokową, nowej zabudowy. 


\subsection{KIERUNEK PRZEKSZTALCEŃ PRZESTRZENNYCH SLOMNIK}

Rys. 2 przedstawia syntezę miejscowego planu zagospodarowania przestrzennego uwzględniającą zróżnicowanie postulowanego planem zagospodarowania terenus. Wskazane na rysunku planu tereny o różnym sposobie użytkowania zostały pogrupowane w oparciu o podobne parametry i wskaźniki (wielkość działek, wysokość zabudowy i wskaźnik jej powierzchni).

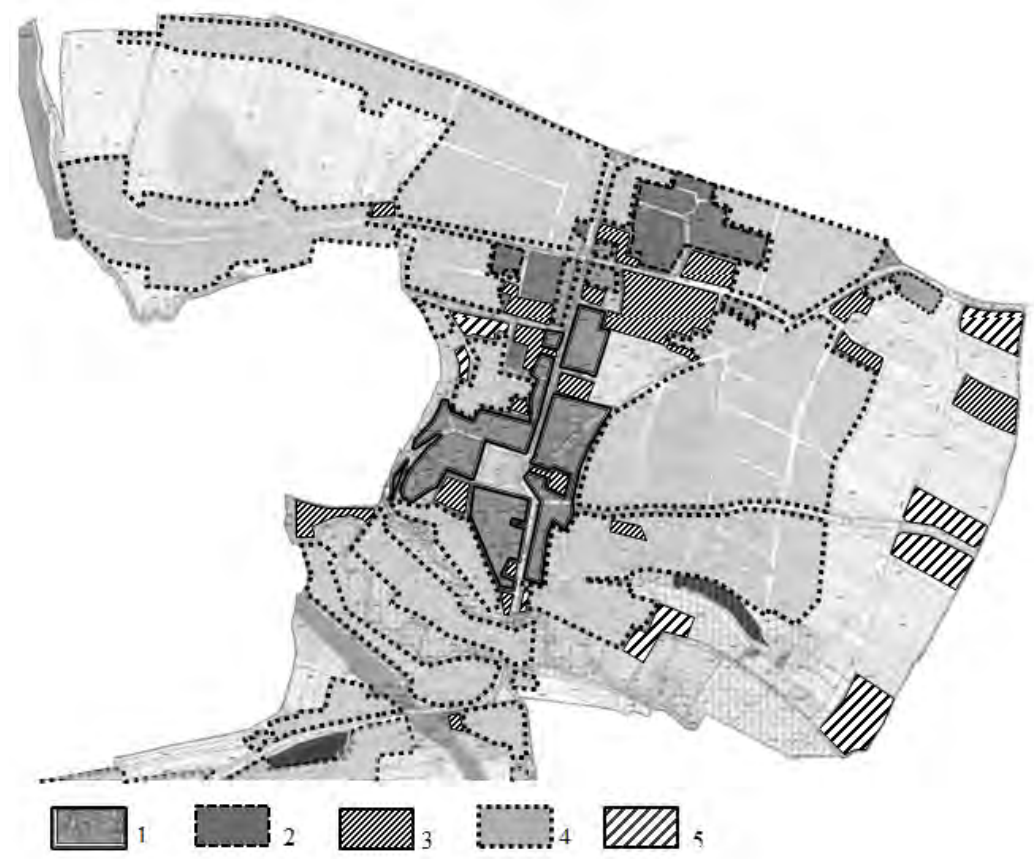

1 - tereny zabudowy mieszkaniowej śródmiejskiej i tereny zabudowy mieszkaniowo-usługowej

2 - tereny zabudowy mieszkaniowej wielorodzinnej

3 - tereny zabudowy usług publicznych i komercyjnych

4 - tereny zabudowy mieszkaniowej jednorodzinnej, zabudowy mieszkaniowo-usługowej

5 - tereny zabudowy produkcyjno-usługowej

Rys. 2. Synteza ustaleń miejscowego planu zagospodarowania przestrzennego

Słomnik obszarów o podobnych wskaźnikach i parametrach zabudowy

Źródło: opracowanie własne na podstawie mpzp Słomnik (Uchwała... 2015)

5 Syntezę przedstawiono z pominięciem terenów znajdujących się w południowej części miasta, za linią kolejową terenów przynależnych administracyjnie do Słomnik. Ze względu na ich położenie za nasypem kolejowym tworzącym barierę przestrzenną oraz dużego rozproszenia zabudowy nie są zintegrowane z miastem. 
Zwarte, typowe dla struktur miejskich tereny zabudowy mieszkaniowej śródmiejskiej i mieszkaniowo-usługowej, zabudowy mieszkaniowej wielorodzinnej, zabudowy usług publicznych i komercyjnych na rysunku posiadają oznaczenia 1-3. Rozwój terytorialny tutaj obejmuje powiększenie zespołu zabudowy wielorodzinnej i położonych przy nim usług publicznych. Najwięcej nowych terenów przeznaczono w planie pod zabudowę jednorodzinną i mieszkaniowo-usługową. Od sposobu ich zorganizowania - w zakresie form grup zabudowy, funkcji uzupełniających, głównych ciągów pieszych i ulic, zależeć będzie charakter przestrzeni miejskiej.

Planowane kierunki przekształceń miasteczka powinny służyć rozwiązaniu problemu, jakim jest postrzeganie jego przestrzeni jako nieatrakcyjnej, o grożącej deformacji układu urbanistycznego i zaniku jego cech miejskich. Jest to skutek postępującej degradacji strefy śródmiejskiej, prowadzeniu środkiem miasta tranzytu rozbijającego jego zwartość, skłonności do wprowadzania budownictwa wzdłuż dróg. Tendencje rozwojowe, głównie polegające na powstawaniu osiedli jednorodzinnych, wiążą się przede wszystkim z przekształcaniem miasta w zaplecze mieszkaniowe dla osób pracujących i korzystających z usług poza nim. Może to doprowadzić do przekształcenia Słomnik w podmiejskie osiedle ze zniszczonym starym miastem. Zabudowa w formie domów jednorodzinnych staje się dominującą w obszarze miasta (rys. 2, oznaczenie 4). Obecna przestrzeń Słomnik o wyraźnym charakterze formy miejskiej wynika z istniejących elementów krystalizacji jego kształtu powstałych i narastających w przeszłości. Należy do nich rynek z prostopadle od niego wychodzącymi ulicami, dominująca w panoramie sylweta kościoła, wzgórze z piętrzącą się po nim zabudową oraz ul. Kościuszki tworząca oś miasta. Te najistotniejsze elementy kompozycyjne wymagają utrwalenia, a czytelność układu w nowo powstających zespołach zabudowy zapewnić powinny powiązanie ich $\mathrm{w}$ jeden organizm przy pomocy przestrzeni publicznych tworzących ulice, place oraz urządzone tereny zieleni.

\subsection{WNIOSKI}

Definicję małego miasta podaną przez S. Gzella w książce pt. Fenomen małomiejskości (Gzell 1996) brzmiącą: „Małe miasto to czytelne w planie i zwarte przestrzennie zgrupowanie niewielkiej liczby budowli na niewielkim terytorium oraz niewielkie zgrupowanie ludzi, którym te budowle służą, a także interakcje zachodzące pomiędzy tymi elementami i wewnątrz nich ${ }^{6}$ " w pełni można zastosować do Słomnik.

${ }^{6}$ Określenie „niewielkie” dotyczy ilości mieszkańców mniejszej niż 30 tys. 
Skala miasteczka, rdzeń miasta tworzony przez jego najstarszy układ, silne powiązanie wizualne $\mathrm{z}$ otaczającym otwartym krajobrazem, umieszczają je w grupie typowych małych miast.

Analizy dla Słomnik obejmowały aktualny stan miasta (wrzesień 2015) oraz przewidywane jego zagospodarowanie wynikające $\mathrm{z}$ wprowadzania zapisów miejscowego planu zagospodarowania przestrzennego (Uchwała... 2015) w odniesieniu do kształtu przestrzeni miejskiej. Prowadzą one do konkluzji:

- Słomniki posiadają czytelne cechy formy miejskiej. Są to przede wszystkim zwartość zabudowy oraz utrzymana linia zabudowy w centralnej części miasta, a także główny plac miejski, jakim jest rynek;

- zapisy mpzp utrwalają małomiejski charakter centralnej części miasta poprzez wielkość zabudowy, jej lokalizację, zachowanie istniejących elementów kompozycji i urządzenia przestrzeni publicznej;

- wskazane w mpzp parametry zabudowy dają możliwość kształtowania struktury miejskiej, choć z racji elastycznych zapisów nie dają gwarancji jej realizacji jako zwartych zespołów;

- rozwój przestrzenny w nowych terenach nakierowany jest na zespoły zabudowy jednorodzinnej o cechach podmiejskich, bez wydzielenia komponentów układu zapewniających jego czytelność i wprowadzania przestrzeni publicznych łączących z centralną częścią miasta;

- dalsza degradacja tkanki starego miasta grozi utratą jej śródmiejskiego znaczenia - realizacja planu wymaga znalezienia narzędzi umożliwiających jego skuteczne wdrażanie.

Należy stwierdzić, że polityka przestrzenna lokalnych władz wyrażona w miejscowym planie wynika ze świadomości potrzeby utrzymania obecnego małomiasteczkowego charakteru Słomnik. Zapisany postulatywnie w planie sposób kształtowania przestrzeni wpisuje się w parametry istniejącej zabudowy.

Stan przestrzeni miejskiej i obecne tendencje wprowadzania zabudowy Słomnik jest typowy dla dużej liczby innych małych miast, które głównie rozwijają się jako zespoły mieszkaniowe. Nie wszystkie jednak posiadają narzędzie, jakim jest mpzp. Uchwalenie miejscowego planu dla całego miasta w jego granicach administracyjnych skutkuje jednoznacznym określeniem granic zainwestowania, uniemożliwiając rozlewanie się zabudowy. Wewnętrzna budowa miasta przekształcana indywidualnie, regulowana wskaźnikami o skrajnych wielkościach (maksymalnych lub minimalnych) umożliwia, ale nie zapewnia utrzymania harmonii wizualnej. Dla tak małych struktur, jakimi są miasteczka, gdzie każda nowa forma zabudowy bardzo oddziałuje na otoczenie, wytyczne dotyczące budynków i ich usytuowania powinny być doprecyzowane. 
Przedstawione zagadnienia są charakterystyczne dla wielu małych miast, jednak tylko część z nich posiada określone prawnie zasady rozwoju, które sprzyjają utrzymaniu lokalnej tożsamości. Definiowanie kształtu przestrzennego, ochrona istniejących jego komponentów i kreowania nowych, dbałość o przestrzeń publiczną i walory krajobrazu są bardzo istotne dla odbioru miasta i wpływają na jakość jego środowiska, również na komfort życia mieszkańców.

Przeciwdziałanie zanikania klimatu małego miasta na skutek rozwoju terenów rozproszonej zabudowy jednorodzinnej oraz przypadkowych lokalizacji budynków halowych wymaga określenia zasad regulacji przestrzennych i konsekwentnej polityki przestrzennej przy ich wprowadzaniu.

\section{LITERATURA}

Archiwum Map WIG, KdwR_F41_Slomniki_1914_600dpi.jpg, http://igrek.amzp.pl/details.php?id $=10841$.

Adamczewska-Wejchert H., Wejchert K., 1986, Mate miasta. Problemy urbanistyczne stale aktualne, Arkady, Warszawa.

Bank Danych Lokalnych GUS, http://stat.gov.pl/bdl/app/miejsc_w.display?p_id=8709\& p_token $=0.8174589001573622 \#$.

Bartosiewicz B., Marszał T. (red.), 2011, Struktura przestrzenna małych miast-z perspektywy 20 lat transformacji, Wydawnictwo Uniwersytetu Łódzkiego, Łódź.

Czepczyński M., 2012, Przestrzeń publiczna jako forma reprezentacji spoleczności lokalnych. Między hibernacja a animacja centrów małych miast woj. pomorskiego, [w:] Heffner K., Marszał T. (red.), Przestrzeń publiczna małych miast, „Studia KPZK PAN", 144, s. 7-19.

Gołąb-Korzeniowska M., 2008, Małe miasta Krakowskiego Obszaru Metropolitalnego jako zaplecze mieszkalne Krakowa, [w:] Heffner K., Marszał T. (red.), Ośrodki lokalne w strefie oddzialywania wielkich miast, „Biuletyn KPZK PAN”, 238, s. 50-61.

Groeger L., 2012, Przestrzeń publiczna małego miasta w opinii mieszkańców (przykład Łasku), [w:] Heffner K., Marszał T. (red.), Przestrzeń publiczna małych miast, „Studia KPZK PAN", 144, s. 123-134.

Gzell S., 1996, Fenomen małomiejskości, Wydawnictwo Akapit - DTP, Warszawa.

Heffner K., Marszał T. (red.), 2011, Rewitalizacja, gentryfikacja i problemy rozwoju mabych miast, „Studia KPZK PAN”, 136, Warszawa.

Malik R., 2013, Stomniki. Charakterystyka budowy przestrzennej miasta średniowiecznego w oparciu o analizę wielkości dziatki lokacyjnej, „Wiadomości Konserwatorskie”, 33 , s. $47-53$.

Sokołowski D., 2000, Charakterystyka funkcjonalna zbioru matych miast $i$ dużych osiedli wiejskich w Polsce, ,Acta Universitatis Nicolai Copernici”, Geografia, 30, http://www. kpbc.ukw.edu.pl/dlibra/plain-content?id=18925.

Wójtowicz-Wróbel A., 2008, Problemy i szanse przebudowy małego miasta w obszarze oddziatywania Krakowa (przykład Stomnik), [w:] Heffner K., Marszał T. (red.), Ośrodki lokalne w strefie oddziatywania wielkich miast, „Biuletyn KPZK PAN”, 238, s. 181-191. 
Wójtowicz-Wróbel A., 2013, Wspótczesne problemy przeobrażeń matych miast w rejonie oddziaływania Krakowa - na wybranych przykładach, Rozprawa doktorska Kraków, Biblioteka Cyfrowa Politechniki Krakowskiej.

Uchwała Nr IX/80/15 Rady Miejskiej w Stomnikach z dnia 27 sierpnia 2015 r. w sprawie uchwalenia miejscowego planu zagospodarowania przestrzennego Miasta Stomniki, Dziennik Urzędowy Województwa Małopolskiego, Kraków, dn. 4 września 2015 r., poz. 5166.

\begin{abstract}
The article concentrates on the issues of the form of a small city, whose evolution is determined by implementation of the provisions of the local plan. The examination of the actual development of the area and its spatial conditions makes it possible to diagnose the most significant problems connected with the municipal structure. The MPZP analysis allows to determine the nature of the space that may arise in the course of its execution and consequences for spatial order of the built-up space and legibility of the system. The study was conducted for Słomniki, the place that is an example of a small city with a preserved mediaeval layout and features of spatial transformations characteristic of this type of urban settlement. The city is included in the local development plan passed in 2015 .
\end{abstract}

\title{
Keywords
}

Small city, municipal form, zoning plan, Słomniki. 